\title{
Research on the Method of Improving the Innovation Ability of Industrial Design Students Based on Design Competition
}

\author{
Feng Zhang \\ Ningbo Institute of Technology \\ Zhejiang University \\ Ningbo, China
}

\author{
Weiwei Wang \\ Zhejiang Textile and Fashion College \\ Ningbo, China
}

\begin{abstract}
This paper takes industrial design competition as one of the methods to improve students' innovation ability, straightens out the relationship between design competition and design teaching, summarizes its application rules in industrial design teaching system, and proposes corresponding solutions to possible problems. The method is promoted and applied in the industrial design related practice, so as to improve the students' enthusiasm for learning and maximize the students' innovative design ability.
\end{abstract}

Keywords-industrial design; design competition; innovation; capacity improvement

\section{INTRODUCTION}

In the new era, social development, economic transformation, industrial upgrading, and improvement of living standards all require creative design to enhance competitiveness. The importance of design has become the national consensus. For the practitioners of the design industry, the key is to have a high-quality education level and professional quality talents that meet the needs of global development.

The discipline research of industrial design is solving problems with creative methods based on discovering problems in life, and cultivating the ability of design talents to cross-apply logical thinking and image thinking in the process of solving problems. The application and practicality of the design discipline is particularly important. Practice is the platform for testing the theoretical framework of the discipline as well as the standard for testing the application capabilities of design. As an important means to enhance the professional ability of industrial design and test the level of design and application, the design competition has received more and more attention from the design education community. There are more than 10 international industrial design competitions held each year, such as the German Red Dot Award, IF Award, Taiwan Lite-On, China Red Star Award, Feng Award and so on, and the small-scale special design competition sponsored by the government and enterprises is countless. In this context, how to use the industrial design discipline competition to explore ways to effectively improve students' innovation ability is a new topic in the field of design education.

As a new market product, the design competition conveys the voice of the market and the enterprise, and provides a new teaching method for the teaching practice of industrial design and the improvement of students' innovative ability. At present, in the curriculum of some universities in China, the design competition has begun to be embedded in the industrial design teaching system. However, it must also be seen that there is a certain difference between what the competition focuses on and what is taught by design education. In order to pursue high award rates, many schools use competition as the main content of design course in the teaching process, and participate in design competitions regardless of their priorities. Although it can not only improve the school's popularity in a short period of time, but also provide students with post-graduation employment capital, from the overall process of design education, it cannot completely replace the teaching content of design education. At the same time, it must be noted that the application of the design competition in the industrial design curriculum system is not very systematic, and has not yet formed the model and method for effectively utilizing the design discipline competition to enhance students' innovation ability. This is also the problem that this article mainly researches and strives to solve.

\section{ANALYSIS OF THE NECESSITY OF INTEGRATING DESIGN PROFESSIONAL COMPETITION INTO PRACTICAL TEACHING SYSTEM OF INDUSTRIAL DESIGN}

\section{A. Design Competition Has Become an Intuitive and Quantitative Standard for Professional Evaluation in Colleges and Universities}

At present, the scale of design education in China and the speed of development have exceeded the normal state. So far, there are nearly one million students studying design related majors in China. Such a huge scale of school running in China requires a relatively objective standard to measure the effectiveness of running a school. Due to the cross characteristics of the industrial design discipline, it is impossible to fully apply the quantitative standards of the 
engineering system since there are many uncertainties and factors that cannot be quantified. Therefore, the level and quantity of professional competition become a quantifiable reference standard to judge the effectiveness of running a school. Therefore, more and more colleges and universities across China use this as a benchmark and reference system, and the professional design competition is listed as an indispensable part of the teaching system of industrial design.

At the same time, with the increasing influence of the German Red Dot Award, IF Award, US IDSA, Japan GMARK Award and other international competitions, these international authoritative competitions have become the weight to measure the strength and achievements of professional schools. German Red Dot Award as an example was once known as "Design Oscar" because of its high international recognition degree. At present, in the domestic design industry and the education sector, the "red dot boom" has been launched. The annual finalist rate of similar large international events is only $2 \%$ to $6 \%$, and its judging criteria are very strict, which makes these international events establish their authority in the industry. Therefore, if the colleges that offer design majors can win the red dot award, it is to some extent a powerful verification of the effectiveness of college design majors.

\section{B. Professional Competition Has Gradually Become a Bridge That Enterprises and Government Use to Connect Students and Society}

With the development of the domestic economy, more and more enterprise units are aware of the value of industrial design. Due to the lack of professional designers, coupled with the need for a large number of design scheme with mass producibility for product upgrading, some companies have gradually begun to use industrial platform to carry out industrial design-related competitions, trying to acquire design scheme in a short period of time through this "short, flat, and fast" method to shorten the product development cycle. This is the original intention of domestic enterprises establishing relevant professional design competitions. Through the design competition, a large number of design schemes can be obtained. The professional competition platform can be a platform for discovering and reserve professional design talents and publicizing the enterprise itself. In addition, more and more government agencies begin to hold professional design competitions, which have played the role of government in the macro-control of the industrial entity. It is conducive to promoting the development of relevant local industries and the establishment of relevant mechanisms. Therefore, professional competition has gradually become a bridge that enterprises and the government use to connect students and society, which plays an important role.

\section{Incorporating the Competition into Some Daily Teaching Links Will Help Strengthen the Students' Internal Knowledge System and Enhance the Effect of "Inner Training"}

The so-called "inner training" refers to the profession related basic skills and basic methods that are learned in the lower grades of the undergraduate course. These knowledge need to be tested and consolidated through practice. With a moderate and healthy competition platform, it helps to stimulate students' interest in learning. The professional design competition is regarded as the stage for "practice" to exercise the basic techniques that have been learned to achieve the purpose of practice making perfect. In addition to practicing basic techniques and methods, it is more important to train students' thinking. Techniques can be mastered through practice, and thinking can be agile through training. One of the benefits of participating in domestic and international competitions is that it can guide students to think about important issues and phenomena that are attracting attention in the world, turn them into design problems and solve them with creative thinking.

\section{With the Help of Industrial Design Competition, We Can Solve the Problem of Imbalance in Professional \\ Development and Regional Restraint}

From the perspective of China's manufacturing industry clusters, the layout of industrial design development is mainly distributed in coastal areas. In recent years, China has vigorously advocated the development of cultural and creative industries, and excellent creative resources are concentrated in cities with relatively developed economies. The uneven distribution of traditional formats and resources has also brought certain regional constraints to design education. For example, colleges and universities opening design major in Central and Western areas or regions with slower economic development, often struggle to find a suitable social platform for students to participate in the actual design practice when it comes to the corresponding professional practice and graduation practice, resulting in blind action and idle theorizing. Relevant professional competitions have to some extent compensated for the lack of regional resources for practice. In recent years, many industrial design competitions have been held in China. Many of the topics are from the real propositions of enterprises. Students can overcome the problems of regional differences and participate in the design practice of real propositions through participation.

\section{The Possible Problem IN INTROdUCING INDUSTRIAL DESIGN COMPETITIONS INTO THE CURRICULUM SYSTEM}

In the introduction of the industrial design competition into the industrial design teaching system, some problems have also been discovered, mainly reflected in the following two aspects.

\section{A. If Too Many Students Are Involved in Professional Competitions, It Is Easy to Mislead Students into Thinking That Attending Competition Is the Main Purpose of Professional Learning}

Participating in professional competitions is only one part of industrial design education, instead of the whole content. The significance of design is not to create beautiful product models, but to explore the interactive relationship between products and humans, and make people aware that there are 
many essential problems in the environment formation system behind the daily life. "Industrial design should be based on the problems in life, focus on the relationship between people, products and the environment, and explore the essential issues that many designs should focus on, rather than just focusing on the glamorous aspects of competition and awards.

\section{B. If the Award Is Simply Used as the Standard for Evaluating Students' Professional Ability, It Is Easy for Students to Have the Value of Quick Success}

Relatively speaking, the finalist rate of domestic professional competition is relatively high while that of large international design competition is relatively low, let alone winning prizes. It is not easy to stand out from thousands or even tens of thousands of works from all over the world, so participants should not put too much pressure on themselves. Once they win the competition, they will be accompanied by applause, honors and even attractive bonuses. If they think of the design competition as a process and a tool, it may be a good place to become famous and practice their skills, but it is by no means an end point of profession.

Teachers should actively guide students to weigh the gains and losses in the teaching process, cultivate students' correct values, and let students not arbitrarily set limits for themselves for gains and losses, and do not pursue the merits and demerits brought by the competition. Students can gain experience by participating in the competition. There are not many design clients, so the design competition can be regarded as a customer to practice and challenge.

\section{APPLICATION METHOD OF INDUSTRIAL DESIGN COMPETITION IN TEACHING SYSTEM}

\section{A. Clearing the Relationship Between Design Competition and Design Education, and Adjusting the Corresponding Teaching Content and Methods}

From an overall perspective, the purpose of design teaching and design competition is a relationship between the whole and the part. Industrial design education advocates the overall understanding and systematic learning of industrial design, while the design competition only focus on the design results and performance of a certain product or a certain theme. Only aiming for blindly obtaining awards, carrying out teaching by highlighting the content needed for the design competition, and neglecting the cultivation of the basic design ability will inevitably affect the integrity of the industrial design education system.

There are many commonalities between design competition and design teaching. The final design orientation of both design education and design competition is the test of social needs. Design competition is like a weather vane for design needs. If the professional teacher can analyze and filter some hidden market information in design competition, adjust the teaching content in time, and set up a special research topic, the promoting effect of design competition on the industrial design education will be more prominent. Therefore, it is very important to clarify the relationship between the two to carry out reasonable coordination and find the right balance.

\section{B. Arranging the Design Competition Time According to the Student's Learning Process and Mentality}

Organizing students to participate in the right competition at the right time is a key issue in the industrial design teaching system. Generally speaking, the students of industrial design majors entered the product design stage in the second year of the university, but the students at this stage are not suitable to participate in the industrial design competition. The first half of the second year of the university is the stage when students complete the initial understanding of the industrial design process and form the basic design thinking. Students cannot express the design ideas in the appropriate industrial design language at this stage because their basic knowledge and performance ability are still incomplete. Thus, the blind participation in the competition will disrupt the normal process of design learning. At the same time, the lower grade students do not have a mature attitude towards the award. The result of success or failure is likely to cause blind self-confidence and unnecessary inferiority, which is not conducive to further completing the design education.

Therefore, the design competition can start from the second half of the second grade or the third grade because at this stage, students have already understood the relatively complete design procedure and have the ability to express the design ideas, which is in the stage of deepening and expanding the design. Participating in the design competition not only allows them to creatively apply what they have learned and understand the dominant trends in the market and design fields as soon as possible, but also facilitates them to know the design opponents in the same field nationwide and improve their innovation ability.

\section{Selecting the Design Competition Content Discriminatively and Guiding the Design Process in a Targeted Manner}

Industrial design competitions can be divided into three types: concept type, topic type, and practice type. In the introduction of the design competition into the teaching, it is necessary to fully screen the content of the design competition, so as to "select the design competition content discriminatively and guide the design process in a targeted manner." Moderate participation in design competitions is beneficial to students' development to a certain extent. However, if the number competition is too much, and the category and content is not selected, not only will it affect the normal teaching work of the school, but the student will be influenced by the limitations of design competition, resulting in the illusion that actual design content and design competition are the same. Therefore, it is especially important that teachers need to assist students in choosing to participate in design competitions. This requires that professional teachers be familiar with various forms of design competition and grasp the balance point between design teaching and design practice to make rational use of design competition. 


\section{APPLICATION AND ACHIEVEMENTS OF DESIGN COMPETITION IN INDUSTRIAL DESIGN TEACHING OF OUR UNIVERSITY}

According to the research results of the subject, the industrial design teachers can firstly classify different types of competitions and select the important ones. For each grade level and different time periods, teachers can organize students to participate in the competition selectively with different focuses. During the second year and the first half of the third year, students should focus on the conceptual and topic design competition. During the second half of the third grade and the fourth year, students should participate in the practical design competition. According to the actual situation, the teachers will sort the industrial design competitions to be participated in each year according to the time sequence, and finally determine the competitions to be participated in that year. The selected design competition is then linked to the teaching session in the aspects of curriculum time and course content. As for the design competition that has a certain distance from the course content, teachers should make a decisive adjustment.

After a period of time since the introduction of competition, the teacher summarizes the student's entries and the award-winning works, and establishes an industrial design competition database. By analyzing different types of design competitions and winning works, summarizing relevant experiences and awarding rules, they can provide students with reference materials for participating in relevant competitions in the future.

Since the introduction of the industrial design competition into the industrial design teaching system, our school has achieved great results. By the end of 2018, we have won the German Red Dot Industrial Design Competition Award for 7 consecutive years. The school has been rated as one of the top ten universities in Asia Pacific by the Red Dot Organization and our students have also won many awards in the domestic competition. By participating in international competitions, students not only achieved international recognition, but also greatly enhanced their self-confidence in learning.

\section{CONCLUSION}

By clearing the relationship between design competition and design teaching, the application rules of industrial design professional competition in industrial design teaching system are summarized, the implementation method of introducing industrial design competition into teaching is put forward, and some measures are taken to ensure that the method can be smoothly applied in the industrial design related practice.

On the one hand, the application of this method can create a communication platform for industrial design students, extract the benign market information in the design competition, break through the practical barriers of design education, and greatly enhance students' enthusiasm for learning and innovation. On the other hand, the experience of participating in the international competition can improve the students' design experience and innovation ability, and use the "scope of knowledge" of the competition to assist the "knowledge point" in the classroom, which promotes the smooth progress of the industrial design teaching. At present, the research results of this paper have been introduced into other design disciplines, which has promoted the enthusiasm of students in designing majors, improved the professional teaching effect, and received wide acclaim.

\section{REFERENCES}

[1] Zeng Xi, Song Yiqin. New ideas for the reform of the competition-aid teaching mode in industrial design majors--taking the industrial design major of Wuhan engineering university as an example [J], Jilin Education, 2015: 10:13. (in Chinese)

[2] $\mathrm{Su} \mathrm{Xu}$. Research on the teaching mode of design ability training based on industrial design and interdisciplinary nature [J]. Art Education Research, 2014, 07: 136. (in Chinese)

[3] He Mingfeng. Driving the cultivation of innovative talents in industrial design by design competition [J]. Design Science, 2012, 06: 151. (in Chinese)

[4] Wen Xixi. The optimization design of practical design for industrial design based on subject competition[J]. Data of Culture and Education, 2018, 23. (in Chinese)

[5] Liu Xin, Wang Lie, Luo Jie. Research on the centralized practice teaching of industrial design major for cultural and creative industries - taking the cultural creative design of maritime silk road as an example[J]. Art Education 2018, No.18. (in Chinese)

[6] Liu Hao, Liu Liming. Application of professional competition in the teaching of industrial design and innovative thinking [J], Industrial Design, 2017-08. (in Chinese)

[7] Liu Yang, Thinking in the teaching of innovative design practice course [J]. Appreciation, 2017-02. (in Chinese)

[8] Zeng Li, Liang Jianian; Re-recognition of the value of professional competition in the industrial design practice teaching system [J], Art Education Research, 2016, 19. (in Chinese) 